\title{
The North/South Ireland Food Consumption Survey: the dietary fibre intake of Irish adults
}

\author{
MA Galvin ${ }^{1, *}$, M Kiely', KE Harrington ${ }^{2}$, PJ Robson ${ }^{3}$, R Moore $^{3}$ and A Flynn ${ }^{1}$
}

Irish Universities Nutrition Alliance (IUNA) at: 'Nutritional Sciences, Department of Food Science, Food Technology and Nutrition, University College, Cork, Republic of Ireland: ${ }^{2}$ Department of Clinical Medicine, Trinity Centre for Health Sciences, St. James's Hospital, Dublin 8, Republic of Ireland: ${ }^{3}$ Northern Ireland Centre for Diet and Health (NICHE), University of Ulster, Coleraine, Co. Londonderry, BT52 1SA, Northern Ireland

\begin{abstract}
Objective: Mean daily intakes of dietary fibre (DF, Southgate) and non-starch polysaccharide (NSP, Englyst) are estimated in a representative sample of adults aged 18-64 years in Ireland. The contribution of food groups to DF and NSP intake is reported and fibre intakes are compared with dietary recommendations and with intakes in some European countries.

Design: Food consumption was estimated using 7-day food diaries for a representative sample ( $n=1379 ; 662$ men, 717 women) of 18-64 year old adults in the Republic of Ireland and Northern Ireland selected from the electoral register. DF and NSP intakes were estimated from tables of food composition.

Results: The mean daily intake of DF in the total sample was $20.2 \mathrm{~g}$ (standard deviation (SD) 7.8) [23.2 $\mathrm{g}$ (SD 8.5) in men, $17.4 \mathrm{~g}$ (SD 5.9) in women] or 2.24 $\mathrm{g} \mathrm{MJ}^{-1}$ (SD 0.7) [2.16 $\mathrm{g} \mathrm{MJ}^{-1}$ (SD 0.7) in men, $2.33 \mathrm{~g} \mathrm{MJ}^{-1}$ (SD 0.7) in women]. Mean daily intake of NSP was $14.8 \mathrm{~g}$ (SD 6.2) [16.7 $\mathrm{g}$ (SD 6.8) in men, $13.0 \mathrm{~g}$ (SD 5.0) in women] or $1.65 \mathrm{~g} \mathrm{MJ}^{-1}$ (SD 0.6) $\left[1.56 \mathrm{~g} \mathrm{MJ}^{-1}\right.$ (SD 0.6) in men, $1.74 \mathrm{~g} \mathrm{MJ}^{-1}$ (SD 0.6) in women]. The main food groups that contributed to mean daily intake of DF (NSP) in the sample were breads $31 \%(23 \%)$, potatoes $19 \%(23 \%)$, and vegetables $17 \%(19 \%)$. Absolute intakes of DF and NSP were higher $(P<0.001)$ in men than women; however, women overall consumed more $(P<0.001)$ fibre-dense diets than men. Women aged 18-35 years consumed less $(P<0.01)$ DF and NSP $(g)$ than women aged 36-64 years. Both men and women aged 18-35 years consumed less $(P<$ 0.01 ) fibre-dense diets than men and women aged 36-64 years. The NSP intake was below the nutritional goal of $18 \mathrm{~g} \mathrm{day}^{-1}$ in $77 \%$ of adults and below the minimum of the recommended range $\left(12 \mathrm{~g} \mathrm{day}^{-1}\right.$ ) in $37 \%$ of the total sample. Compliance (i.e. the maximum number of individuals whose collective mean daily intake corresponded to the population goal) with the (UK) population goal for an average intake of $18 \mathrm{~g} \mathrm{day}^{-1}$ NSP was achieved by a greater proportion of the population (63\%) than compliance with the (German) dietary fibre recommendation of $30 \mathrm{~g} \mathrm{day}^{-1}$ (27\%) or the (Nordic) recommendation of $3 \mathrm{~g} \mathrm{MJ}^{-1} \mathrm{day}^{-1}$ (33\%).

Conclusion: DF (NSP) intakes were lower than dietary recommendations in a substantial proportion of the population. This is likely to contribute to impaired bowel function and constipation, which in turn may contribute to increased risk of chronic gastrointestinal disease.
\end{abstract}

Keywords
Dietary fibre
Non-starch polysaccharide
Intake
Adults
Recommendations
Compliance
Food groups
Ireland

While there is no consensus on a single definition for dietary fibre or on the methodology of fibre determination $^{1}$, a widely accepted definition is 'the remnants of plant cells resistant to hydrolysis by human alimentary enzymes $^{2}$. Its main chemical constituents are hemicelluloses, celluloses, lignin, pectins, gums and waxes ${ }^{2}$. However, the chemical composition of dietary fibre varies with the method of measurement. For example, analysis by the Southgate method $^{3}$ to measure 'dietary fibre' (DF) includes hemicelluloses, celluloses, lignin, pectins, gums, waxes and resistant starch while analysis by the Englyst method $^{4}$ to measure 'non-starch polysaccharide' (NSP) includes all of these constituents except lignin and resistant starch.

Dietary fibre has received much attention since its first link with health in the $1970 \mathrm{~s}^{5}$ and has been associated with a reduced risk of diseases such as colon cancer and cardiovascular disease among Western populations ${ }^{6}$. 
Dietary fibre has a laxative effect and increases stool weight, which helps to reduce the incidence of constipation $^{7}$. Clinical evidence has established the role of high fibre intakes in improving glycaemic control and insulin sensitivity in diabetics and in obese diabetics, and maintaining a healthy gastrointestinal tract ${ }^{6,8}$. Epidemiological studies suggest that dietary fibre or foods rich in fibre, especially cereal products, can exert a protective effect against coronary heart disease ${ }^{9,10}$. The COMA working group on Diet and Cancer concluded that moderate evidence is available to link higher dietary fibre intakes to reduced incidence of colorectal and possibly pancreatic cancer ${ }^{11}$. However, recent randomised controlled intervention studies indicate that fibre does not reduce the risk of colorectal cancer ${ }^{12,13}$. Dietary fibre is also present in foods that contain phytochemicals, which may exert a protective effect against different types of cancer ${ }^{14}$.

In 1991, the COMA panel on Dietary Reference Values (DRVs) recommended that, in order to reduce the incidence of bowel disease, average NSP intake for the adult population should be $18 \mathrm{~g} \mathrm{day}^{-1}$, with an individual range of $12-24 \mathrm{~g} \mathrm{day}^{-1}$, and the NSP should be consumed from a variety of foods that contain it as a naturally integrated component ${ }^{15}$. The COMA panel on Diet and Cancer endorsed this recommendation in $1999^{11}$. In Europe recommended intakes of total dietary fibre generally fall between 20 and $35 \mathrm{~g} \mathrm{day}^{-1}$ and dietary guidelines generally recommend an increased consumption of fruits, vegetables, cereals and cereal products ${ }^{16}$. The German Nutrition Society recommends a mean daily population intake of $30 \mathrm{~g}$ or more for dietary fibre ${ }^{17}$. In Sweden the mean daily population target for dietary fibre density is set at $3 \mathrm{~g} \mathrm{MJ}^{-1}$, which approximates to $25-35 \mathrm{~g}$ of dietary fibre ${ }^{18}$. In the Republic of Ireland, up-to-date quantitative dietary fibre recommendations have not been established.

Current estimates of dietary fibre intake in the Republic of Ireland and Northern Ireland are based on surveys conducted over 10 years ago ${ }^{19,20}$. Mean dietary fibre intake was estimated at $18.7 \mathrm{~g} \mathrm{day}^{-1}$ among adults aged 18-64 years in the Republic of Ireland in $1990^{19}$ and $18.1 \mathrm{~g} \mathrm{day}^{-1}$ among adults aged $16-64$ years in Northern Ireland in $1989^{20}$. This paper estimates the current intake of DF and NSP in Irish adults aged 18-64 years and describes the contribution made by major food groups to DF and NSP intake. It uses data collected from 7-day food diaries completed in the North/South Ireland Food Consumption Survey. The results are compared with previous estimates of mean daily dietary fibre intake in Ireland and in other European countries and with dietary recommendations for dietary fibre intake.

\section{Methods}

A more detailed account of the methodology and sampling procedure used in the North/South Ireland Food Consumption Survey has been described in two other papers in this supplement publication ${ }^{21,22}$.

Individuals were randomly selected using the electoral register as the sampling frame and participation was invited among adults aged 18-64 years, except for pregnant or lactating women. Food intake data were measured in 1379 respondents (662 males and 717 females) ${ }^{22}$.

A 7-day food diary was used to collect food intake data and a variety of methods were used to quantify food intake including direct weighing of some foods, a specially designed photographic food atlas and food manufacturers' product data ${ }^{21}$.

Food intake data were analysed using WISP $^{\odot}$ (Tinuviel Software, Warrington, UK). WISP ${ }^{\odot}$ uses data from McCance \& Widdowson's The Composition of Foods, fifth edition $^{23}$ plus supplemental volumes ${ }^{24-32}$ to generate nutrient intake data. The WISP ${ }^{\odot}$ database was expanded to include nutrient data on generic Irish foods that were commonly consumed. Two values for fibre are shown in the food composition tables: dietary fibre (DF) measured by the Southgate method ${ }^{3}$, which includes soluble fibre, insoluble fibre, lignin and some resistant $\operatorname{starch}^{23}$, and total non-starch polysaccharide (NSP) measured by the Englyst method ${ }^{4}$, which includes soluble fibre and insoluble fibre ${ }^{23}$ but excludes lignin and resistant starch. In the remainder of this paper the term 'dietary fibre', as opposed to DF, is used in cases where the method of analysis of dietary fibre is unspecified. The data handling and processing procedures used have been described elsewhere in this supplement ${ }^{21}$.

Data analysis was carried out using SPSS ${ }^{\circledR}$ Version 9.0 for Windows ${ }^{\mathrm{TM}}$ (SPSS Inc., Chicago, IL). Mean \pm standard deviation (SD), median and the 5th and 95th percentiles for DF and NSP intake were calculated by sex and age group (18-35 years, 36-50 years and 51-64 years). Independent $t$-tests were used to assess differences between mean intakes in men and women. One-way analysis of variance (ANOVA) with post boc multiple comparisons was used to determine whether or not differences in mean intakes between age groups existed within sex. Where significant differences between age groups existed, comparisons of means were made using the Scheffe post boc multiple comparisons test to identify which means differed between age groups. For values that did not comply with Levene's test for homogeneity of variance, i.e. DF $(\mathrm{g})$ and NSP ( $\mathrm{g}$ and $\mathrm{g} \mathrm{MJ}^{-1}$ ) in females, the Tamhane post boc multiple comparisons test was used to identify which means differed between age groups. Values of $P$ less than 0.01 were taken as statistically significant.

In order to identify a subgroup of the total sample who were successful in meeting recommended population mean daily intakes of $30 \mathrm{~g}$ of dietary fibre $\mathrm{e}^{17}, 3 \mathrm{~g} \mathrm{MJ}^{-1}$ of dietary fibre $e^{18}$ or $18 \mathrm{~g}$ of $\mathrm{NSP}^{15}$, an approach used by 
Wearne and Day ${ }^{33}$ and described by the Ministry of Agriculture, Fisheries and Food (MAFF) ${ }^{34}$ was used. The individual mean daily intake of DF ( $\mathrm{g}$ and $\mathrm{g} \mathrm{MJ}^{-1}$ ) and NSP $(g)$ in the total sample was ranked from highest to lowest. Starting from the highest intake, successive individuals were added until the addition of one more caused the average of the group to fall below the recommended population mean intake. This approach identified the maximum number of people in the subgroup whose collective mean daily intake met the population target, and this subgroup was referred to as 'compliers' (although some compliers had intakes that fell short of the population target). The remainder of individuals were referred to as 'non-compliers'.

The contribution ( $\%$ and $\mathrm{g} \mathrm{day}^{-1}$ ) of major food groups to DF and NSP intakes were calculated for men and women. Owing to the large sample size, even small differences between the group means, in terms of contribution of food groups to DF and NSP intake, were highly statistically significant. Greater emphasis was therefore placed on a descriptive, rather than a formal statistical analysis of these data.

\section{Results}

Table 1 shows the mean daily intake of DF and NSP in adults, categorised by sex and age group. The mean daily intake of DF in the total sample was $20.2 \mathrm{~g}$ (23.2 $\mathrm{g}$ in men and $17.4 \mathrm{~g}$ in women) and mean daily intakes were significantly higher $(P<0.001)$ in men than women for all corresponding age groups. The mean daily intake of NSP in the total sample was $14.8 \mathrm{~g}$ (16.7 $\mathrm{g}$ in men and $13.0 \mathrm{~g}$ in women) and mean daily intakes were significantly higher $(P<0.001)$ in men than women for all corresponding age groups. In women, the mean daily intakes of DF and NSP were significantly lower $(P<0.01)$ in the age group 18-35 years than in the age groups 3650 years and 51-64 years. This trend was similar in men, although the difference was not statistically significant.
Table 2 shows the mean daily intake of DF and NSP expressed per MJ of energy in adults categorised by sex and age group. The mean daily intake of DF per MJ of energy in the total sample was $2.24 \mathrm{~g} \mathrm{MJ}^{-1}\left(2.16 \mathrm{~g} \mathrm{MJ}^{-1}\right.$ in men and $2.33 \mathrm{~g} \mathrm{MJ}^{-1}$ in women) and mean daily intakes were significantly higher $(P<0.01)$ in women than men for the corresponding age groups $36-50$ years and 51-64 years. The mean daily intake of NSP per MJ of energy in the total sample was $1.65 \mathrm{~g} \mathrm{MJ}^{-1}\left(1.56 \mathrm{~g} \mathrm{MJ}^{-1}\right.$ in men and $1.74 \mathrm{~g} \mathrm{MJ}^{-1}$ in women) and mean daily intakes were significantly higher $(P<0.01)$ in women than men for all corresponding age groups. In both men and women, mean daily intakes of DF and NSP per MJ of energy were significantly lower $(P<0.01)$ in the age group $18-35$ years than in the age groups $36-50$ years and 51-64 years.

Overall, $37 \%$ of the total sample (25\% of men and $48 \%$ of women) had an NSP intake below the minimum intake $\left(12 \mathrm{~g} \mathrm{day}^{-1}\right)$ recommended by COMA for individuals ${ }^{15}$. A greater proportion of adults aged $18-35$ years, especially women, were below this recommended minimum intake than adults aged $36-50$ years or 51-64 years.

Subgroups of the total sample, whose collective mean daily intake corresponded to the recommended population mean daily intakes of $30 \mathrm{~g}$ of dietary fibre ${ }^{17}, 3 \mathrm{~g} \mathrm{MJ}^{-1}$ of dietary fibre ${ }^{18}$ or $18 \mathrm{~g}$ of NSP ${ }^{15}$, were identified. These subgroups were referred to as 'compliers' and the remainder of the sample was referred to as 'noncompliers'. Table 3 shows 'compliers' and 'non-compliers' in the sample with respect to different fibre recommendations and the mean daily intake of food and drink (g), energy (MJ), DF ( $g$ and $\mathrm{g} \mathrm{MJ}^{-1}$ ) and NSP ( $\mathrm{g}$ ) for each group.

Twenty-seven per cent of the total sample were 'compliers' of the population goal of $30 \mathrm{~g}$ of dietary fibre (with a male to female ratio of 20:7) and the mean daily intake of DF in this group was almost twice that of 'non-compliers' ( $30.0 \mathrm{~g}$ vs. $16.5 \mathrm{~g}$, respectively). 'Compliers' had higher mean daily intakes than 'non-compliers'

Table 1 Mean daily intake of DF and NSP in Irish adults, categorised by sex and age group

\begin{tabular}{|c|c|c|c|c|c|c|c|c|c|c|c|c|}
\hline \multirow[b]{3}{*}{ Sex } & \multirow[b]{3}{*}{ Age group } & \multirow[b]{3}{*}{$n$} & \multicolumn{5}{|c|}{ DF $\left(g\right.$ day $\left.^{-1}\right)$} & \multicolumn{5}{|c|}{$\operatorname{NSP}\left(\mathrm{g} \mathrm{day}^{-1}\right)$} \\
\hline & & & \multirow[b]{2}{*}{ Mean } & \multirow[b]{2}{*}{ (SD) } & \multicolumn{3}{|c|}{ Percentiles } & \multirow[b]{2}{*}{ Mean } & \multirow[b]{2}{*}{ (SD) } & \multicolumn{3}{|c|}{ Percentiles } \\
\hline & & & & & Median & 5 th & 95th & & & Median & 5 th & 95th \\
\hline \multirow[t]{4}{*}{ Men } & $18-35$ years & 253 & 22.6 & (8.5) & 21 & 11.7 & 38.5 & 15.9 & (6.5) & 14.5 & 8.3 & 28 \\
\hline & $36-50$ years & 236 & 23.6 & (8.1) & 22.6 & 12.8 & 38.8 & 17.3 & (6.8) & 16.2 & 8.1 & 32.1 \\
\hline & $51-64$ years & 173 & 23.6 & (8.9) & 21.7 & 12.8 & 42 & 17.3 & (7.1) & 15.7 & 9.1 & 31.5 \\
\hline & $18-64$ years & 662 & 23.2 & (8.5) & 21.8 & 12.1 & 38.9 & 16.7 & (6.8) & 15.4 & 8.3 & 30 \\
\hline \multirow[t]{4}{*}{ Women } & $18-35$ years & 269 & $16.1^{a}$ & (5.1) & 15.2 & 8.8 & 25.7 & $11.8^{\mathrm{a}}$ & (4.1) & 11 & 6.5 & 19.9 \\
\hline & $36-50$ years & 286 & $18.2^{b}$ & (6.3) & 17.2 & 10.7 & 28.5 & $13.6^{b}$ & (5.2) & 12.7 & 7.4 & 21.9 \\
\hline & $51-64$ years & 162 & $18.2^{\mathrm{b}}$ & $(6.2)$ & 17.6 & 8.8 & 28.2 & $14.0^{b}$ & (5.4) & 13.4 & 6.4 & 25.2 \\
\hline & $18-64$ years & 717 & 17.4 & (5.9) & 16.6 & 9.3 & 27.5 & 13.0 & (5.0) & 12.1 & 6.7 & 21.4 \\
\hline All & $18-64$ years & 1379 & 20.2 & (7.8) & 18.9 & 10.4 & 35.5 & 14.8 & (6.2) & 13.6 & 7.2 & 26.7 \\
\hline
\end{tabular}

${ }^{\mathrm{ab}}$ Denotes a significant difference $(P<0.01)$ between means of age groups within sex.

Differences between means for men and women in corresponding age groups were significant $(P<0.001)$ in all cases. 
Table 2 Mean daily intake of DF and NSP expressed per MJ of energy, by sex and age group

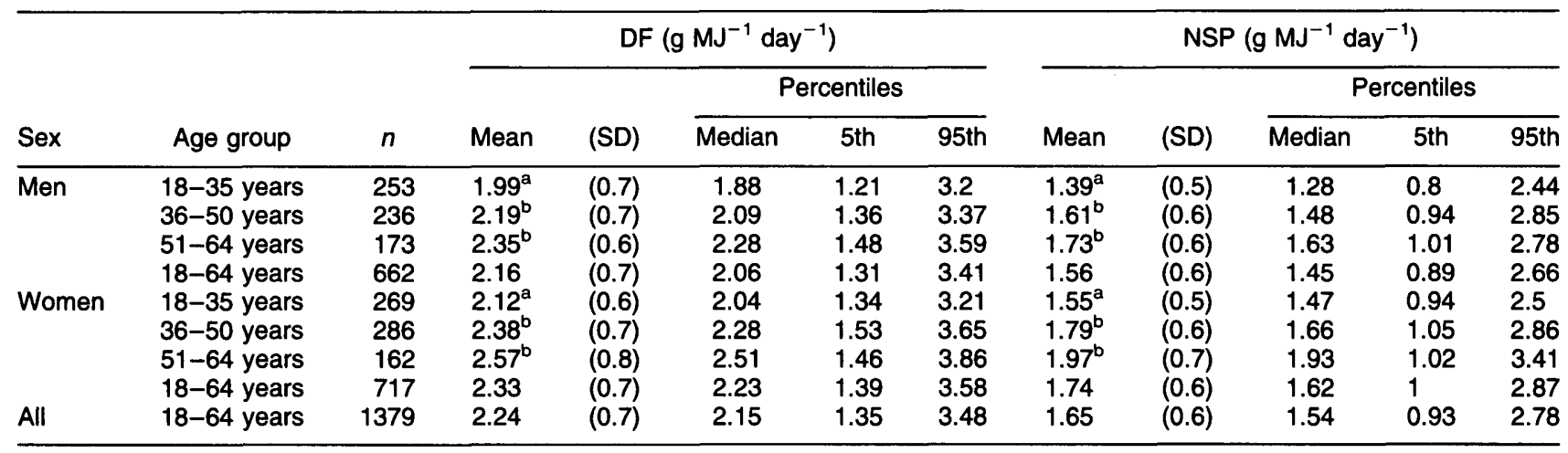

${ }^{\mathrm{ab}}$ Denotes a significant difference $(P<0.01)$ between means of age groups within sex.

Differences between means for men and women in corresponding age groups were significant $(P<0.01)$ in all cases, except for the $18-35$ year age group between men and women for DF $\left(\mathrm{g} \mathrm{MJ}^{-1}\right)$.

for weight of food and drink consumed (3448 $\mathrm{g}$ vs. $2556 \mathrm{~g}$ ), energy intake (11.8 MJ vs. $8.3 \mathrm{MJ}$ ) and DF density $\left(2.67 \mathrm{~g} \mathrm{MJ}^{-1}\right.$ vs. $\left.2.08 \mathrm{~g} \mathrm{MJ}^{-1}\right)$.

Thirty-three per cent of the total sample were 'compliers' of the population goal of $3 \mathrm{~g} \mathrm{MJ}^{-1}$ of $\mathrm{DF}$ (with a male to female ratio of 13:20) and the mean daily intake of DF per $\mathrm{MJ}$ of energy in this group was substantially higher $\left(3.00 \mathrm{~g} \mathrm{MJ}^{-1}\right)$ than in 'non-compliers' $\left(1.87 \mathrm{~g} \mathrm{MJ}^{-1}\right)$. 'Compliers' had similar mean daily intakes to 'non-compliers' of food and drink ( $2740 \mathrm{~g}$ vs. $2832 \mathrm{~g}$ ), lower mean daily intakes than 'non-compliers' of energy (8.3 MJ versus $9.7 \mathrm{MJ}$ ) and higher mean daily absolute intakes than 'non-compliers' of DF ( $24.8 \mathrm{~g}$ vs. $17.9 \mathrm{~g}$ ).

Sixty-three per cent of the total sample were 'compliers' of the population goal of $18 \mathrm{~g}$ NSP (with a male to female ratio of 36:27) and the mean daily intake of NSP in this group ( $18.0 \mathrm{~g})$ was almost twice that of 'non-compliers' (9.4 g). 'Compliers' had higher mean daily intakes than 'non-compliers' for weight of food and drink consumed ( $3051 \mathrm{~g}$ vs. $2384 \mathrm{~g}$ ), energy intake (10.3 MJ vs. $7.5 \mathrm{MJ}$ ) and DF density (2.45 $\mathrm{g} \mathrm{MJ}^{-1}$ vs. $\left.1.89 \mathrm{~g} \mathrm{MJ}^{-1}\right)$.

Table 4 shows the mean daily contribution of food groups to DF and NSP intakes in men and women. The contributions of food groups to DF (contribution to NSP) were as follows: breads $31 \%(23 \%)$, potatoes $19 \%$ (23\%), vegetables $17 \%(19 \%)$, fruit and nuts $8 \%(8 \%)$, and breakfast cereals $8 \%(8 \%)$. Overall, breads, potatoes and vegetables collectively provided two-thirds of the DF and NSP consumed in the diet.

\section{Discussion}

The mean daily absolute intake of DF and NSP was higher in men than women but when expressed per MJ of energy consumed, the mean daily intake of DF and NSP was higher in women than men. This shows that absolute intakes of DF and NSP were higher in men because they consumed more food and drink but women consumed more fibre-dense diets. Women in the 18-35 year age group consumed less fibre and less fibre-dense diets than women in the 36-50 year and 51-64 year age groups. Men in the 18-35 year age group consumed less fibredense diets than men in the 36-50 year and 51-64 year age groups and while the trend was similar for absolute intakes of DF and NSP, the results were not statistically significant.

Reported mean daily intakes of $20.2 \mathrm{~g}$ of DF, $2.24 \mathrm{~g} \mathrm{MJ}^{-1}$ of DF or $14.8 \mathrm{~g}$ of NSP were less than the published recommended population mean intakes of 30 g dietary fibre ${ }^{17}, 3 \mathrm{~g} \mathrm{MJ}^{-1}$ dietary fibre ${ }^{18}$ or $18 \mathrm{~g} \mathrm{NSP}^{15}$,

Table 3 Mean daily intake of food and drink (g), energy intake (MJ), DF ( $g$ and $g \mathrm{MJ}^{-1}$ ) and NSP (g) in 'compliers' and 'non-compliers' of the DF and NSP recommendations in the total population

\begin{tabular}{|c|c|c|c|c|c|c|}
\hline \multirow[b]{2}{*}{ Recommendations } & \multicolumn{3}{|c|}{ 'Compliers' } & \multicolumn{3}{|c|}{ 'Non-compliers' } \\
\hline & $30 \mathrm{~g} \mathrm{DF}$ & $3 \mathrm{~g} \mathrm{MJ}^{-1} \mathrm{DF}$ & $18 \mathrm{~g} \mathrm{NSP}$ & $30 \mathrm{~g} \mathrm{DF}$ & $3 \mathrm{~g} \mathrm{MJ}^{-1} \mathrm{DF}$ & $18 \mathrm{~g} \mathrm{NSP}$ \\
\hline $\begin{array}{l}n \text { (\% of population) } \\
\text { Cut-off value to achieve goal }{ }^{*} \\
\text { Mean daily intakes }\end{array}$ & $\begin{array}{l}379(27 \%) \\
\geq 23.38\end{array}$ & $\begin{array}{c}459(33 \%) \\
\geq 2.42\end{array}$ & $\begin{array}{l}863(63 \%) \\
\geq 12.04\end{array}$ & $\begin{array}{c}1000(73 \%) \\
<23.38\end{array}$ & $\begin{array}{c}920(67 \%) \\
<2.42\end{array}$ & $\begin{array}{l}516(37 \%) \\
<12.04\end{array}$ \\
\hline $\begin{array}{l}\text { Total food and drink }(\mathrm{g}) \\
\text { Energy }(\mathrm{MJ}) \\
\text { DF }(\mathrm{g}) \\
\text { NSP }(\mathrm{g}) \\
\text { DF }\left(\mathrm{g} \mathrm{MJ}^{-1}\right)\end{array}$ & $\begin{array}{c}3448 \\
11.8 \\
30 \\
22.2 \\
2.67\end{array}$ & $\begin{array}{c}2740 \\
8.3 \\
24.8 \\
18.7 \\
3\end{array}$ & $\begin{array}{c}3051 \\
10.3 \\
24.1 \\
18 \\
2.45\end{array}$ & $\begin{array}{c}2556 \\
8.3 \\
16.5 \\
12 \\
2.08\end{array}$ & $\begin{array}{c}2832 \\
9.7 \\
17.9 \\
12.8 \\
1.87\end{array}$ & $\begin{array}{c}2384 \\
7.5 \\
13.6 \\
9.4 \\
1.89\end{array}$ \\
\hline
\end{tabular}

* The cut-off value is the minimum individual mean daily intake of DF $\left(\mathrm{g}\right.$ or $\mathrm{g} \mathrm{MJ}^{-1}$ ) or of $\mathrm{NSP}(\mathrm{g})$ that generates a mean daily intake of $30 \mathrm{~g}$ of $\mathrm{DF}, 3 \mathrm{~g} \mathrm{MJ} \mathrm{Of}^{-1}$ of DF or $18 \mathrm{~g}$ of NSP, respectively, in a population whose mean daily intake is ranked from highest to lowest. 


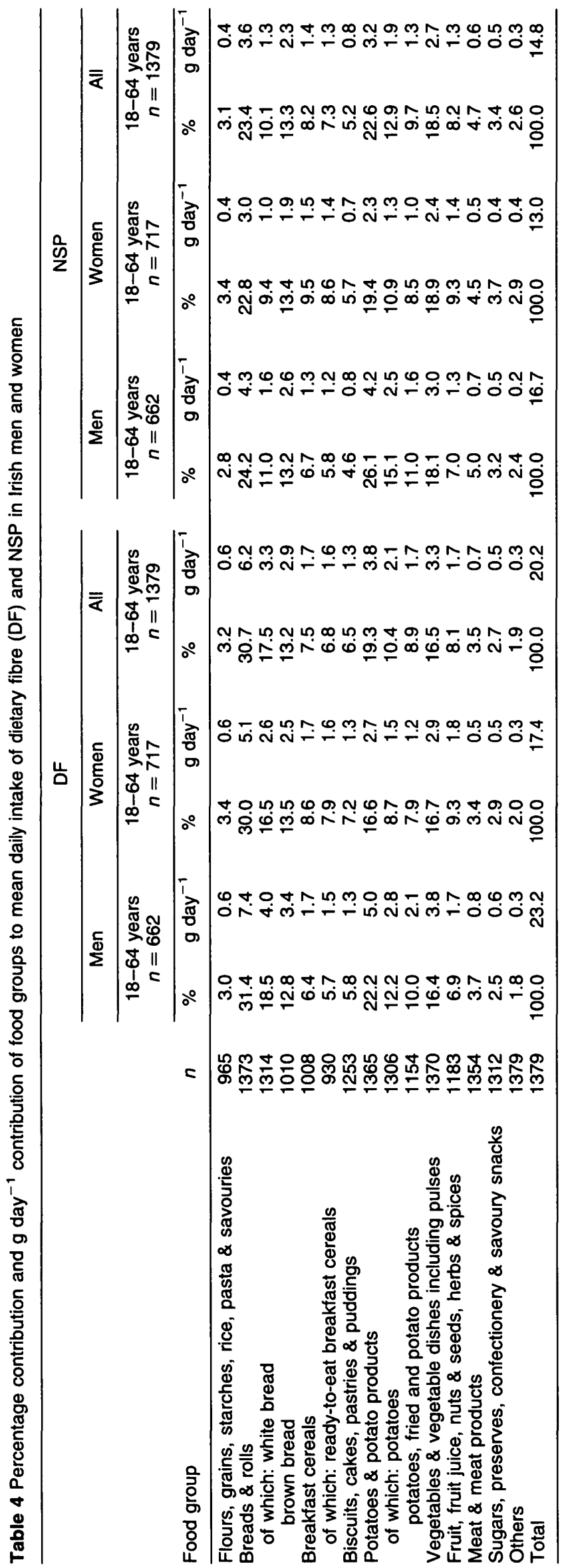

respectively. The NSP intake was below the nutritional goal $^{15}$ of $18 \mathrm{~g} \mathrm{day}^{-1}$ in $77 \%$ of adults $(67 \%$ of men and $87 \%$ of women) and below the minimum of the recommended range $\left(12 \mathrm{~g} \mathrm{day}^{-1}\right)^{15}$ in $37 \%$ of the total sample ( $25 \%$ of men and $48 \%$ of women). This trend was most marked in the age group 18-35 years for both men and women. It is likely to contribute to impaired bowel function and constipation, which may in turn contribute to increased risk of chronic gastrointestinal disease ${ }^{15}$.

The approach outlined by Wearne and Day ${ }^{33}$ was used to evaluate compliance with dietary recommendations and to determine the maximum number of 'compliers' of these recommendations. The advantage of this approach is that the division of the study population is not arbitrary as it uses recommended population intakes to differentiate between groups. In addition, it is consistent with the theoretical derivation of DRVs for dietary fibre and NSP, which are population averages as opposed to targets for individuals ${ }^{33}$.

Only $27 \%$ of the total sample (male to female ratio $20: 7$ ) were 'compliers' of the $30 \mathrm{~g}$ dietary fibre recommendation and $33 \%$ of the total sample (male to female ratio 13:20) were 'compliers' of the $3 \mathrm{~g} \mathrm{MJ}^{-1}$ dietary fibre recommendation. While the recommendation of $3 \mathrm{~g} \mathrm{MJ}^{-1}$ was more likely to be achieved by women than men, the $30 \mathrm{~g}$ dietary fibre recommendation appeared to be largely unachievable by women. In the Dietary and Nutritional Survey of British Adults (1991), a greater proportion of the adult population $(36 \%$, with a male to female ratio of 20:16) were 'compliers' of the recommended population goal of $30 \mathrm{~g} \mathrm{DF}$ per day ${ }^{33}$. In the current survey, $63 \%$ of the total sample (male to female ratio 36:27) were 'compliers' of the $18 \mathrm{~g}$ NSP recommendation and women were only slightly less likely than men to achieve compliance. Thus, the NSP recommendation of $18 \mathrm{~g}$ appears to be a more feasible population target to achieve than the dietary fibre targets of $30 \mathrm{~g}$ or the $3 \mathrm{~g} \mathrm{MJ}^{-1}$, given current dietary practices in adults in Ireland. An NSP intake of $18 \mathrm{~g}$ equates to a DF intake of approximately $25 \mathrm{~g}$ based on population food intakes in this survey. The scientific basis for establishing quantitative recommendations for dietary fibre intake is still weak and few recommendations are based on quantitative evaluation of bowel function or health outcome in relation to fibre intake. In the UK, the DRV of $18 \mathrm{~g}$ for NSP is based on minimising the number of individuals with low stool weights, which are associated with a greater risk of bowel disease ${ }^{15}$. More research needs to be undertaken to examine quantitative relationships of fibre intake and health outcome.

'Compliers' of the recommendations based on absolute intakes ( $30 \mathrm{~g}$ dietary fibre, $18 \mathrm{~g} \mathrm{NSP}$ ) consume more food and drink (by weight) than 'non-compliers', which is consistent with a previous observation in UK adults ${ }^{33}$, and also have higher energy intakes and more fibre-dense diets than 'non-compliers'. However, 'compliers' of the 


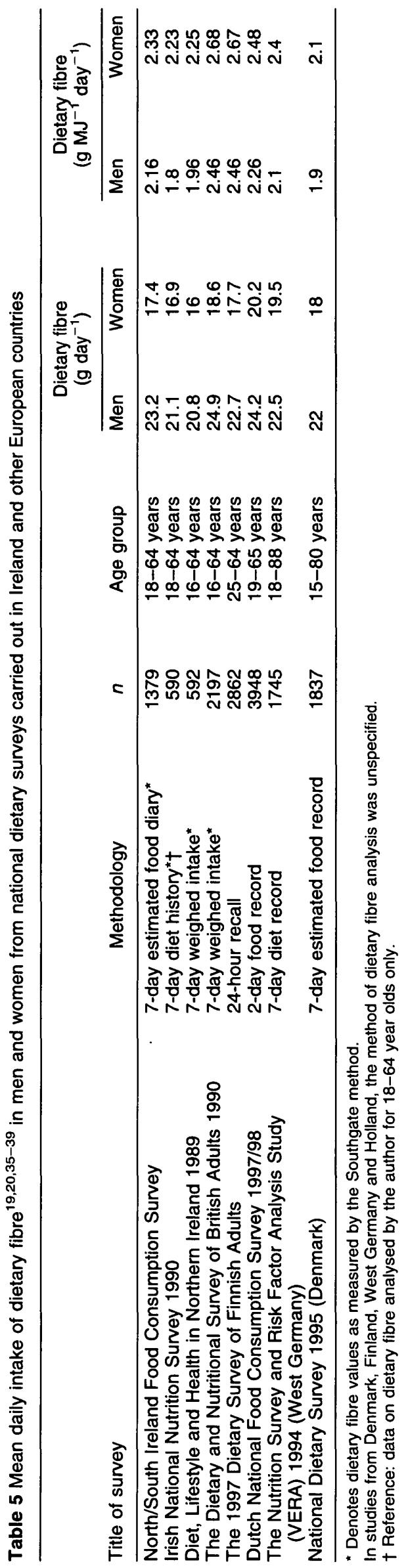

dietary fibre recommendation of $3 \mathrm{~g} \mathrm{MJ}^{-1}$ had a similar intake of food and drink to 'non-compliers' and a lower energy intake. Compliance with recommendations based on absolute intakes of fibre, but not with recommendations based on fibre density, is strongly influenced by total food and drink consumption and total energy intake. It should be noted that estimates of compliance could be confounded by mis-reporting of food consumption ${ }^{33}$.

Table 5 reports the mean daily intake of dietary fibre ( $\mathrm{g}$ and $\mathrm{g} \mathrm{MJ}^{-1}$ ) in men and women from national dietary surveys in other European countries. The mean daily intake of dietary fibre $(\mathrm{g})$ in the current survey was comparable to mean daily intakes in other European countries. The mean daily intake of dietary fibre expressed as $\mathrm{g} \mathrm{MJ}^{-1}$ in the current survey was lower than intakes in the $\mathrm{UK}^{35}$, Finland ${ }^{36}$, Holland ${ }^{37}$ and West Germany (for women only) ${ }^{38}$, and was slightly higher than intakes in Denmark ${ }^{39}$. Mean daily intakes of DF $\left(\mathrm{g} \mathrm{MJ}^{-1}\right)$ in the current survey were, however, higher than values reported in the Irish National Nutrition Survey, $1990^{19}$ and the survey for Diet, Lifestyle and Health in Northern Ireland ${ }^{20}$, in 1989, particularly for men. The contribution of food groups to DF in the current survey was similar to the Irish National Nutrition Survey, $1990^{19}$, except in 1990 vegetables and pulses contributed more than potatoes to DF intake, while in the current survey potatoes contributed more than vegetables and pulses to DF intake. However, it must be noted that comparisons of dietary fibre intakes between populations are difficult due to differences in the methodologies used to estimate food consumption and in the analysis of dietary fibre ${ }^{40}$.

\section{Conclusion}

Absolute intakes of DF and NSP were higher in men than women; however, women consumed more fibre-dense diets than men. The diets of women aged 18-35 years were lower in fibre and less fibre-dense than the diets of women aged 36-50 years or 51-64 years; a similar observation was made in men although it was significant for fibre density only. Overall, breads, potatoes and vegetables collectively provided two-thirds of the dietary intake of DF and NSP. The NSP intake was below the nutritional goal ${ }^{15}$ of $18 \mathrm{~g} \mathrm{day}^{-1}$ in $77 \%$ of adults and below the minimum of the recommended range $\left(12 \mathrm{~g} \mathrm{day}^{-1}\right)^{15}$ in $37 \%$ of the total sample. This is likely to contribute to impaired bowel function and constipation, which in turn may contribute to increased risk of chronic gastrointestinal disease ${ }^{15}$. Only a minority of the total sample achieved compliance with the (German) recommendation $^{17}$ of $30 \mathrm{~g}$ dietary fibre $(27 \%)$ or the (Nordic) recommendation ${ }^{18}$ of $3 \mathrm{~g} \mathrm{MJ}^{-1}$ dietary fibre (33\%). The recommendation of $3 \mathrm{~g} \mathrm{MJ}^{-1}$ dietary fibre was more achievable for women than men, while the $30 \mathrm{~g}$ dietary fibre recommendation was largely unachievable by women. Compliance with the recommendation of $18 \mathrm{~g}$ 
NSP (approximately equivalent to $25 \mathrm{~g}$ of DF) was far more achievable by the population and women were only slightly less likely than men to achieve compliance. Achieving compliance with recommendations based on absolute intakes, but not fibre density, is strongly influenced by the amount of food and drink consumed, and energy intake. More research is needed to establish dietary fibre recommendations that are based on stronger scientific evidence of bowel function and health outcome in relation to fibre intakes. Further analysis of the current data to assess the patterns of food intake, anthropometric measurements and health and lifestyle characteristics of 'compliers' and 'non-compliers' of the fibre recommendations may prove useful, especially in helping to draft more effective dietary guidelines and to characterise 'noncompliers' of fibre recommendations.

\section{References}

1 Oniang'o RK. Fibre: implications for the consumer. Nutr. Res. 1998; 18(4): 661-9.

2 Prosky $\mathrm{L}$. Insulin and oligofructose are part of the dietary fiber complex. JAOAC 1999; 82(2): 223-6.

3 Southgate DAT. Determination of carbohydrates on foods II: Unavailable carbohydrates. J. Sci. Food Agric. 1969; 20: 331-5.

4 Englyst HN, Cummings JH. An improved method for the measurement of dietary fibre as the non-starch polysaccharides in plant foods. JAOAC 1988; 71: 808-14.

5 Burkitt DP, Trowell HC, eds. Refined Carbohydrate Foods and Disease: Some Implications of Dietary Fibre. London: Academic Press, 1975.

6 Anderson JW, Smith BM, Gustafson NJ. Health benefits and practical aspects of high-fiber diets. Am. J. Clin. Nutr. 1994; 59(Suppl.): 1242S-7S.

7 Johnson IT, Southgate DAT, eds. Dietary Fibre and Related Substances, 1st ed. London: Chapman and Hall, 1994.

8 O'Sullivan KR. Fibre and its role in health and disease. Int. J. Food Sci. Nutr. 1998; 49: S9-12.

9 Wolk A, Manson JE, Stampfer MJ, Colditz GA, Hu FB, Speizer FE, Hennekens CH, Willett WC. Long-term intake of dietary fiber and decreased risk of coronary heart disease among women. JAMA 1999; 281(21): 1998-2004.

10 Rimm EB, Ascherio A, Giovannucci E, Spiegelman D, Stampfer MJ, Willett WC. Vegetable, fruit and cereal fibre intake and risk of coronary heart disease among men. JAMA 1996; 275(6): 447-51.

11 Department of Health. Nutritional Aspects of the Development of Cancer. Report of the Working Group on Diet and Cancer of the Committee on Medical Aspects of Food and Nutrition Policy. London: The Stationery Office, 1999.

12 Alberts DS, Martinez ME, Roe DJ, Guillén-Rodríguez JM, Marshall JR, van Leeuwen JB, Reid ME, Ritenbaugh C, Vargas PA, Bhattacharyya AB, Earnest DL, Sampliner RE and the Phoenix Colon Cancer Prevention Physicians' Network. Lack of effect of a high-fiber cereal supplement on the recurrence of colorectal adenomas. N. Engl. J. Med. 2000; 342: 1156-62.

13 Schatzkin A, Lanza E, Corle D, Lance P, Iber F, Caan B, Shike M, Weissfeld J, Burt R, Cooper MR, Kikendall JW, Cahill J and The Polyp Prevention Trial Study Group. Lack of effect of a low-fat, high-fiber diet on the recurrence of colorectal adenomas. N. Engl. J. Med. 2000; 342: 1149-55.

14 Rowland I. Optimal nutrition: fibre and phytochemicals. Proc. Nutr. Soc. 1999; 58: 415-9.
15 Department of Health. Dietary Reference Values for Food Energy and Nutrients for the United Kingdom. Report of the Panel on Dietary Reference Values of the Committee on Medical Aspects of Food Policy. London: HM Stationery Office, 1991.

16 O'Sullivan KR, Cho SS. Fibre recommendations throughout the world. Int. J. Food Sci. Nutr. 1998; 49: S13-21.

17 Deutsche Gesellschaft fur Ernahrung eV. Empfehlungen fur die Nabrstoffzufubr. Frankfurt: Umschau-Verlag, 1991.

18 Sandstrom B, Lyhne N, Pedersen JL, Aro A, Thorsdottir I, Becker W. Nordic Nutrition Recommendations 1996. Scand. J. Nutr/Naringsforskning 1996; 40: 161-5.

19 Lee P, Cunningham K. Irish National Nutrition Survey 1990. Dublin: Irish Nutrition and Dietetic Institute, 1990.

20 Barker ME, McClean SI, McKenna PG, Reid NG, Strain JJ, Thompson KA, Williamson AP, Wright ME. Diet, Lifestyle and Health in Nortbern Ireland. Coleraine, Northern Ireland: Centre for Applied Health Studies, University of Ulster, 1989.

21 Harrington KE, Robson PJ, Kiely M, Livingstone MBE, Lambe J, Gibney MJ. The North/South Ireland Food Consumption Survey: survey design and methodology. Pub. Health Nutr. 2001; 4(5A): 1037-42.

22 Kiely M, Flynn A, Harrington KE, Robson PJ, Cran G. Sampling description and procedures used to conduct the North/South Ireland Food Consumption Survey. Pub. Health Nutr. 2001; 4(5A): 1029-35.

23 Holland B, Welch AA, Unwin ID, Buss DH, Paul AA, Southgate DAT. McCance \& Widdowson's The Composition of Foods, 5th ed. Royal Society of Chemistry and Ministry of Agriculture, Fisheries and Food. London: HMSO, 1995.

24 Holland B, Unwin ID, Buss DH. Cereals and Cereal Products. Third Supplement to McCance \& Widdowson's The Composition of Foods, 4th ed. Royal Society of Chemistry and Ministry of Agriculture, Fisheries and Food. London: HMSO, 1988.

25 Holland B, Unwin ID, Buss DH. Milk Products and Eggs. Fourth Supplement to McCance \& Widdowson's The Composition of Foods, 4th ed. Royal Society of Chemistry and Ministry of Agriculture, Fisheries and Food. London: HMSO, 1989.

26 Holland B, Unwin ID, Buss DH. Vegetables, Herbs and Spices. Fifth Supplement to McCance E Widdowson's The Composition of Foods, 4th ed. Royal Society of Chemistry and Ministry of Agriculture, Fisheries and Food. London: HMSO, 1991

27 Holland B, Unwin ID, Buss DH. Fruit and Nuts. First Supplement to McCance $\&$ Widdowson's The Composition of Foods, 5th ed. Royal Society of Chemistry and Ministry of Agriculture, Fisheries and Food. London: HMSO, 1992.

28 Holland B, Welch AA, Buss DH. Vegetable Dishes. Second Supplement to McCance $\mathcal{E}$ Widdowson's The Composition of Foods, 5th ed. Royal Society of Chemistry and Ministry of Agriculture, Fisheries and Food. London: HMSO, 1996.

29 Holland B, Brown J, Buss DH. Fish and Fish Products. Third Supplement to McCance \& Widdowson's The Composition of Foods, 5th ed. Royal Society of Chemistry and Ministry of Agriculture, Fisheries and Food. London: HMSO, 1993.

30 Chan W, Brown J, Buss DH. Miscellaneous Foods. Supplement to McCance $\varepsilon$ Widdowson's The Composition of Foods. Royal Society of Chemistry and Ministry of Agriculture, Fisheries and Food. London: HMSO, 1994.

31 Chan W, Brown J, Lee SM, Buss DH. Meat, Poultry and Game. Supplement to McCance \& Widdowson's The Composition of Foods. Royal Society of Chemistry and Ministry of Agriculture, Fisheries and Food. London: HMSO, 1995.

32 Chan W, Brown J, Church SM, Buss DH. Meat Products and Dishes. Supplement to McCance $E$ Widdowson's The 
Composition of Foods. Royal Society of Chemistry and Ministry of Agriculture, Fisheries and Food. London: HMSO, 1996.

33 Wearne SJ, Day MJL. Clues for the development of foodbased dietary guidelines: how are dietary targets being achieved by UK consumers? Br. J. Nutr. 1999; 81(Suppl. 2): S119-26.

34 MAFF (Ministry of Agriculture, Fisheries and Food). The Dietary and Nutritional Survey of British Adults: Further Analysis. London: HMSO, 1994.

35 Gregory J, Foster $\mathrm{K}$, Tyler $\mathrm{H}$, Wiseman $\mathrm{M}$. The Dietary and Nutritional Survey of British Adults. London: OPCS/HMSO, 1990.

36 Anttolainen $M$, Javanainen J, Kaartinen P, Lahti-Koski M, Lauronen J, Mannisto S, Ovaskainen ML, Paajanen $\mathrm{H}$, Pietinen P, Roos E, Valsta L, Virtanen M. The 1997 Dietary Survey of Finnish Adults. Helsinki: National Public Health Institute, 1998.
37 Netherlands Nutrition Centre (Stichting Voedingcentrum Nederland). Third National Food Consumption Survey (1997/1998) [Zo eet Nederland 1998 Resultaten van de Voedselconsumptiepeiling]. Van Marken Delft Drukkers, Delft, 1998.

38 Heseker H, Aldolf T, Eberhardt W, Hartmann S, Herwig A, Kubler W, Matiaske B, Moch K, Nitsche A, Schneider R, Zipp A. The Nutrition Survey and Risk Factor Analysis Study (VERA) [Lebensmittel- und Nabrstoffaufnabme Erwachsener in der Bundesrepublik Deutschland. Vera-Schriftenreibe $B d$. III]. Niederkleen: Wissenschaftlicher Fachverlag, 1994.

39 Andersen NL, Fagt S, Groth MV, Hartkopp HB, Moller A, Ovesen L, Warming DL. Danish Dietary Habits 1995. Publication No. 235. Copenhagen: Danish Veterinary and Food Administration, 1996.

40 Bingham S. Definitions and intakes of dietary fiber. Am.J. Clin. Nutr. 1987; 45: 1226-31. 